\title{
Effects of process variables on physical characteristics of tri-component elastic-conductive composite yarns (t-ECCYs) using a modified ring frame
}

\section{REZUMAT - ABSTRACT}

\section{Efectele variabilelor de prelucrare asupra proprietăților fizice ale firelor compozite elastic conductoare tri-componente (t-ECCY) utilizând o mașină de filat cu inele modificată}

S-a demonstrat procedura de fabricație a firelor compozite elastice, conductoare, tri-componente (t-ECCY) cu arhitectură distinctivă, care utilizează un filament de elastan ca miez și un filament din oțel inoxidabil, combinat cu mătase artificială, prin înfășurare elicoidală, în jurul miezului extensibil. A fost aplicată o singură tehnică de analiză factorială pentru a investiga efectele variabilelor de prelucrare, adică spațiul dintre fasciculele de fibre, nivelul de torsiune și viteza fusului, asupra unor properietăți fizice și geometrii de filare ale firelor rezultate, în ceea ce privește tenacitatea la rupere, alungirea la rupere, elasticitatea, pilozitatea, neregularitatea și caracteristicile vizuale. A fost investigat comportamentul electric. Este bine stabilit faptul că variabilele procesului de preparare joacă un rol semnificativ în stabilirea caracteristicilor fizice ale firelor finale. A fost evidențiată relația dintre geometriile de filare și proprietățile firelor. Rezultatele experimentale au arătat că performanțele fizice optimizate ale t-ECCY s-au obținut la o distanță între fascicule de $10,5 \mathrm{~mm}$, torsiune de $700 \mathrm{~T} / \mathrm{m}$ și o viteză a fusului de $7000 \mathrm{rpm}$. Firele $t$-ECCY rezultate ar putea reprezenta o propunere de mare valoare pentru utilizări speciale ale textilelor electrice. Firele sunt disponibile ca element senzor de bază cu o elasticitate substanțială și conductivitate ridicată, pot fi prelucrate cu ușurință în țesături prin tehnologii textile convenționale, oferind țesături cu o bună conservare a formei, pe baza elasticității superioare, cu eficacitate de ecranare electromagnetică prin monofilamentul metalic din interior, cu posibilitati de utilizare în viitor ca dispozitive electronice ușoare în miniatură.

Cuvinte-cheie: fir compozit elastic conductor, variabile de prelucrare, filament de elastan, fir de oțel inoxidabil, textile funcționale, filare cu inele modificată

Effects of process variables on physical characteristics of tri-component elastic-conductive composite yarns (t-ECCYs) using a modified ring frame

The fabrication procedure of tri-component elastic-conductive composite yarns (t-ECCYs) with distinctive architecture, which employs elastane filament as a core and stainless steel filament combining with rayon assemblies as a helical winding around the extensible core, was demonstrated. Then, a single factorial-analysis technique was applied to investigate the effects of processing variables, i.e., strand spacing, twist level and spindle speed, on some physical characteristics and spinning geometries of the resultant yarns, in terms of breaking tenacity, extension at break, elasticity, hairiness, unevenness, and visual features. Then, the electrical behavior was conducted. It is well established that the preparatory process variables play a significant role in deciding the physical characteristics of the final yarns. The Relationship between spinning geometries and yarn properties were highlighted. Experimental results revealed that the optimized physical performances of $t-E C C Y s$ were obtained at $10.5 \mathrm{~mm}$ strand spacing, $700 \mathrm{~T} / \mathrm{m}$ twist, and 7000 rpm spindle speed. The resultant $t$-ECCYs could be a high-valuable proposition for special purposes in electrical textiles. The yarn itself is available as a base sensor element with substantial stretch and high conductivity, and such yarns could be easily processed into fabrics by conventional textile means offering fabrics with good shape preservation based on superior elasticity, even electromagnetic shielding effectiveness with metal monofilament inside, and can thus be applied as lightweight miniature electronics in the future.

Keywords: elastic-conductive composite yarn, process variables, elastane filament, stainless steel wire, functional textile, modified ring spinning

\section{INTRODUCTION}

Elastic-conductive yarns having the potential to be used in e-textiles have been of a mainstream research direction, and such yarns could enable a spectrum of applications, e.g., electrodes, sensors [1-3]. Moreover, abundant studies of yarns will result in new discoveries that push the boundaries of science forward. In general, elastic-conductive yarns are extensively produced by chemical techniques, but several limitations exist including insufficient adhesion, a complex fabrication procedure, and a large ecological footprint. Making yarns mentioned use physical actions, and yarns that can be easily processed into fabrics using traditional textile means, are desperately needed. However, little information can be found on elastic-conductive composite yarns using spinning method, and the potential of ring spinning for such yarn production is not fully exploited yet 
[2-4]. Therefore, further efforts are still urgent to produce yarns that meet above requirements from the viewpoint of materials exploration and fabrication strategy.

Ring spinning, a versatile technique, is broadly used for producing requested yarns in virtue of prominent structural architecture [5]. It is well established that the process variables and spinning geometry play a crucial role in deciding the characteristics of final yarns. Traditionally, many studies are available on the effects of process variables on some physical properties of two-strand yarns, e.g., core, siro, sirofil [6]. Cheng et al investigated the effects of varying strand spacing and twist multiplier on cotton sirospun yarns and founded that higher spacing gave superior properties in terms of tenacity, trapped strand twist and abrasion resistance [7]. Soltani et al pointed out that fiber-migratory properties are considerably affected by strand spacing and twist multiplier [8]. Gowda et al studied the effects of strand spacing, traveller mass, and spindle speed on the properties of model sirospun yarns [9]. In literature, there is hardly any mention on tri-axial ring spinning of elastic-conductive yarns. Since the behavior of yarns is highly variable and depends on many technological parameters, a systematic study of spinning process and effects of variables on some properties of the resultant yarns are required for optimizing the spinning process as a whole.

Herein, the fabrication of tri-component elastic-conductive composite yarns (t-ECCYs) consisting of stainless steel filament (SSF), elastane filament (EF), and rayon fibers (RFs) was described, and the effects of process variables, viz. strand spacing, twist, and spindle speed, on some physical characteristics of the resultant yarns, were investigated, in detail, in terms of tensile behavior, elastic recovery, hairiness, unevenness, and visual appearances. Thereafter, experiments on resistance were performed systematically. Finally, the avenues for further research were put forward.

\section{EXPERIMENTAL DETAILS}

\section{Raw materials}

In this study, the rayon fibers (RFs) of $1.33 \mathrm{dtex}$ and $38 \mathrm{~mm}$ were used to produce rayon roving (RR) of 568.5 tex. Stainless steel filament (SSF, AISI type $316 \mathrm{~L}$ ) was taken as a conductive material with diameter of $30 \mu \mathrm{m}$. Also, elastane filament (EF) was utilized as an elastic one with linear density of $140 \mathrm{D}$.

\section{Composite yarn manufacturing}

A schematic of t-ECCY production is shown in figure $1, a$. A conventional ring frame is retrofitted with a grooved roller, positive feed rollers and a tension disc. The grooved aluminum roller was precisely designed and installed on the roller-weighting arm to increase the feed-stability of SSF and EF. In detail, it is mounted just above the upper front roller and rotated with it due to its delicate design with two bearings inside. Draft ratio of EF was controlled through speed differences between positive feed rollers and front rollers. The preload of SSF was conducted by a tension disc and measured by a tension meter. In figure $1, b$, the fabrication procedure of yarns involves two steps: (i) combination of RR and SSF, forming a SSF core yarn, at convergence point $A$; (ii) compound formation of SSF core yarn and EF, at convergence point $B$. In addition, the real spinning processes of front-rear views were depicted in figure $1, c-d$. The photographic representations of elongation of specimen-R2 in initial-straighten states are depicted in figure $1, e$. The yarn in initial state has a more bulking morphology compared with the straighten one. It can tolerate strain up to about $300 \%$ without pulling apart,

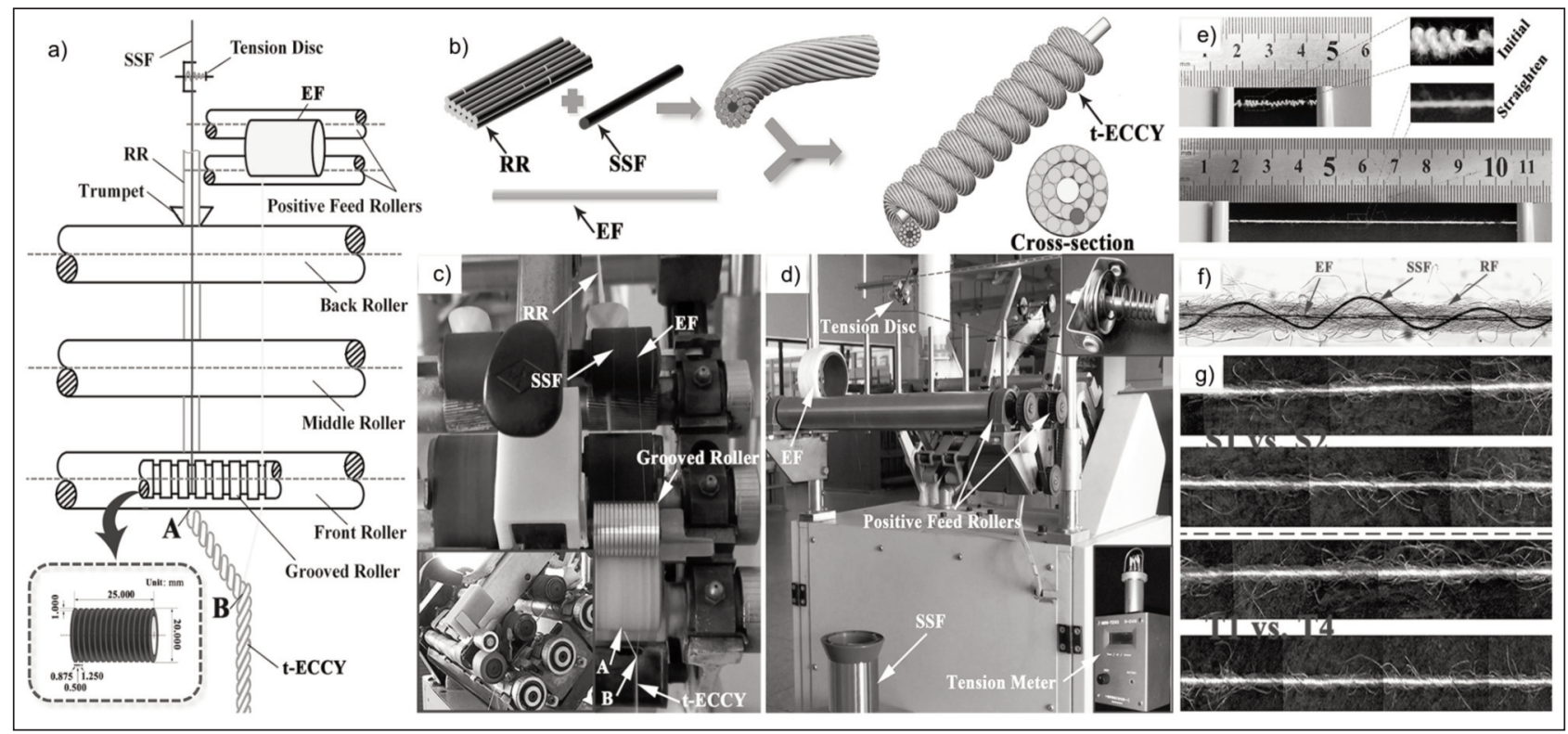

Fig. 1. $a$-schematic of fabrication process of t-ECCY; $b$ - graphic representation of two-step yarn manufacturing; $c-d-$ real process of front-rear views; $e-f-$ photographic representation of elongation of yarns-R2 in initial and straighten states, and positions of EF and SSF inside; $g$ - comparisons of yarn appearances, i.e., S1 vs. S2, T1 vs. T4 


\begin{tabular}{|c|c|c|c|}
\hline Constant parameters & Values & Varying parameters & Values \\
\hline Total draft/Break draft & $18.08 / 1.20$ & Strand spacing/mm & $7.0, \mathbf{1 0 . 5}, 14.0,17.5$ \\
\hline Elastane draft of EF & 3.0 & Twist $/ \mathrm{T} \cdot \mathrm{m}^{-1}$ & $600, \mathbf{7 0 0}, 800,900$ \\
\hline Pretension of SSF/cN & $10-12$ & Spindle speed/rpm & $\mathbf{5 5 0 0 , 7 0 0 0 , 8 5 0 0 , 1 0 0 0 0}$ \\
\hline
\end{tabular}

mainly owing to the specific architecture, which employs EF as a core and SSF as a helical winding around, shown in figure $1, f$. The image was captured by dipping the yarns with $0.5 \mathrm{cN} /$ tex preload in methyl salicylate for a very short time. Also, two photographs (S1 vs. S2, T1 vs. T4) were presented in figure 1, g. A good SSF and EF replacement in the yarn structure was obtained. By contrast, S2 and T4 samples have less hairy compared with $\mathrm{S} 1$ and $\mathrm{T} 1$, respectively. In the field of yarn spinning engineering, processing parameters play a decisive role in influencing the quality characteristics of resultant yarns. The detailed spinning particulars were summarized in table 1. Total 12 yarn specimens, viz., S1-S4, T1-T4, and R1$\mathrm{R} 4$, were fabricated covering preparatory process variables in strand spacing, twist and spindle speed using a single factorial-analysis technique. Noting the process variable value represented in Bold-ItalicType, the relevant yarns were produced by varying one of the three variables, keeping the other two variables constant. For instance, in order to study the spacing-effect, four specimens (S1-S4) were produced at twist of $700 \mathrm{~T} / \mathrm{m}$, and spindle speed of $5500 \mathrm{rpm}$.

\section{RESULTS AND DISCUSSION}

\section{Spinning geometry}

A SONY digital camera was used to capture the spinning geometry in the yarn formation zone [6]. Midway through the spinning, we recorded the process for a certain time, and then we randomly extracted 100 graphs for each condition. The spinning geometries with respect to varying technological parameters were shown in figure 2. As can be seen, the shapes of spinning triangles concerning process variables were obviously asymmetric, primarily due to modulus differences of the two sub-strands, that is, nominal SSF core yarn and EF. Processing variables, e.g., strand spacing, twist, and spindle speed, are vital factors that affect the yarn properties because they control the spinning geometries of the resultant yarns..

\section{Tensile characteristics and rupture behaviour}

The tensile strength was tested at $500 \mathrm{~mm} / \mathrm{min}$ and $500 \mathrm{~mm}$ gauge length. A preload of $0.5 \mathrm{cN} / \mathrm{tex}$ was adjusted. Results from figure $3, a-b$ indicate that with increasing spacing up to $14.0 \mathrm{~mm}$, yarn tenacity and elongation increase beyond which they reduce. Increasing spacing raises applied tension on fibers in the spinning triangle [8]. Further with an increase of spacing, the tension of strands became so great that the convergence point shifts sideways apparently (seen in figure 2, a), causing more unequal stretch in the strands. Due to the poor axial orientation of fibers rather than cohesion, fiber sliding, lower fiber-control [8], and few fiber-loss by pneumafil, tensile behaviors deteriorate consequently [9]. Referring to figure 3,c, the yarn reaches maximum strength at moderate twist $(700 \mathrm{~T} / \mathrm{m})$. If the twist is lower, the sheath does not cover the core properly. Besides, yarn tenacity would decrease with higher twist, mainly due to the decreasing yarn loading capacity and increasing prestress on individual fibers. Regarding the elongation, higher values are obtained with the increasing twist, illustrated in figure 3,d. Shown in figure 3,e, yarn tenacity increases gradually as spindle speed increases. As the speed increases, the force flung by the air loops increases and makes core being wrapped more tightly, heightening the axial strength of yarns. The results from figure $3, f$ reveal that with increasing speed up to $7000 \mathrm{rpm}$, elongation at break increases, beyond which it reduces marginally. The centrifugal force and fiber-loss at $10000 \mathrm{rpm}$ are responsible for the reduced extension. In addition, difference in mean values between groups was analyzed for statistical significance using one-way ANOVA by Minitab 17. As
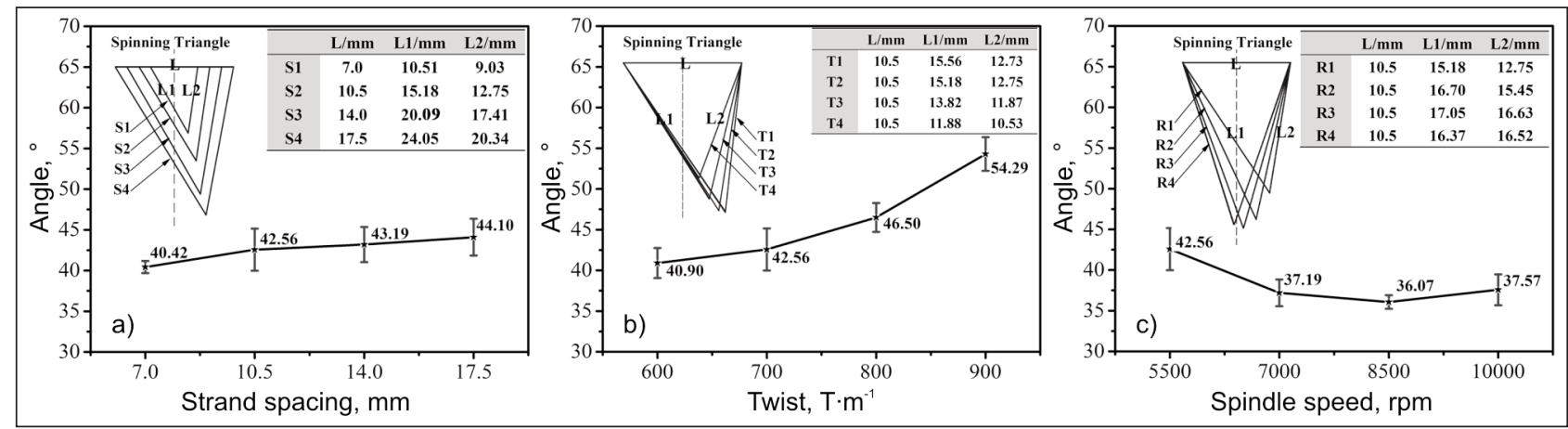

Fig. 2. Relationship between process variables and spinning geometries of the twisting triangle 

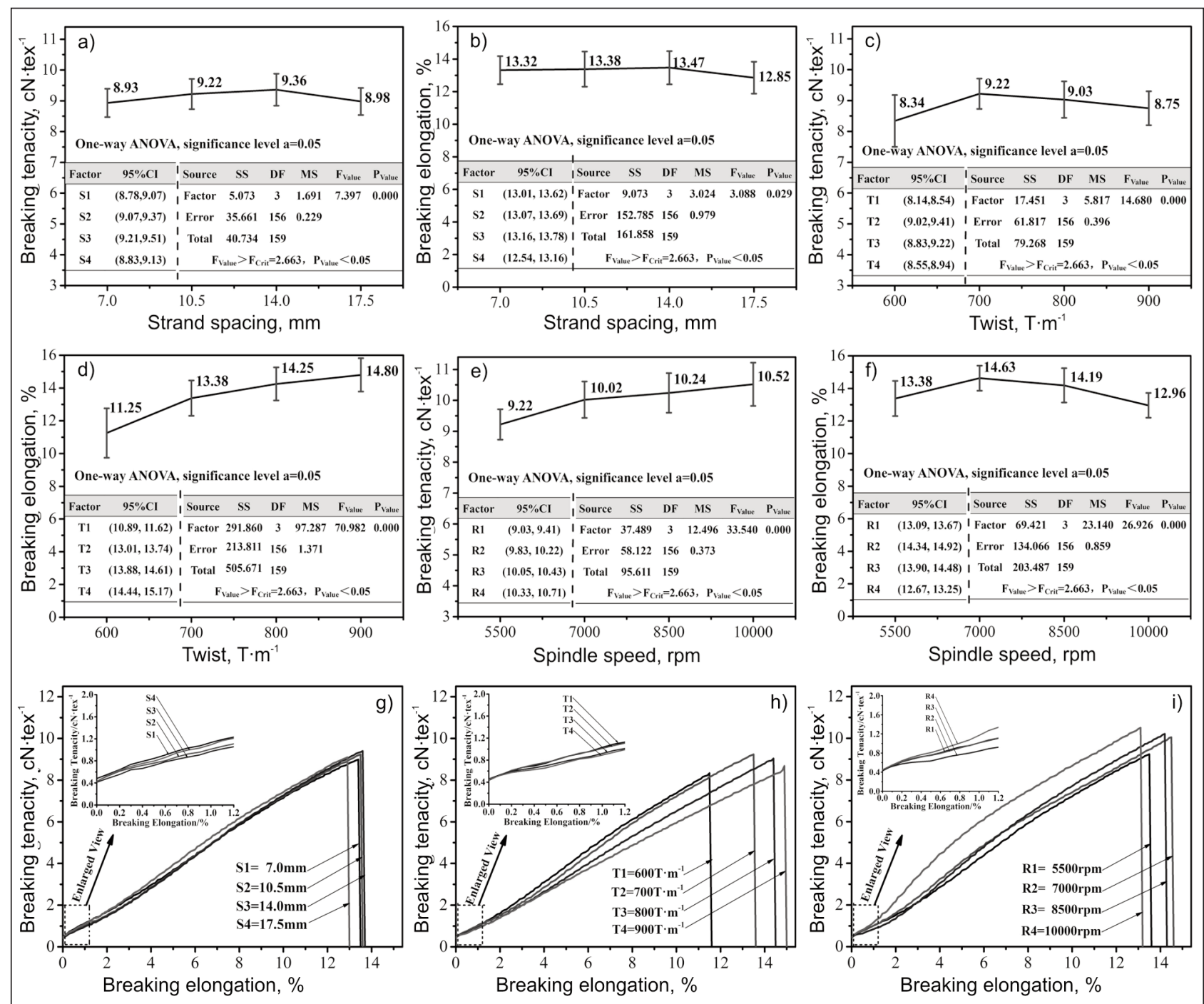

Fig. 3. Effects of process parameters, i.e., $a-b-$ strand spacing, $c-d-$ twist and $e-f-$ spindle speed, on tensile properties of t-ECCYs; typical curves at individual variable of $g$ - strand spacing, $h-$ twist, and $i-$ spindle speed

given, the differences between each process parameter were significant with $\mathrm{P}_{\text {value }}(<0.05)$, demonstrating that the preparatory variables were essential fundamentally.

Typical stress-strain curves of t-ECCYs at varying process variables were graphically displayed in figure $3, g-i$, respectively. The shapes of all the curves are essentially nonlinear, with an initial concavity and a consequent convexity characteristic. A typical characteristic of easily extensible yarns to possess a lower Young's modulus, shown in the dotted rectangle of each graph, was observed due to the presence of EF and helical disposition of SSF inside (figure 1,f). As for figure $3, g$, the characteristics do not change much among the curves obtained at different strand spacing. With respect to figure $3, h$, the mechanical properties of the yarns, especially the elongation at break, are diverse, ranging from about $11.5 \%$ up to $15.0 \%$. In the case of figure $3, i$, the curves obviously shift towards the tenacity axis with an increasing spindle speed.

\section{Elastic recovery}

Elastic recovery was obtained with gauge length of $500 \mathrm{~mm}$, speed of $500 \mathrm{~mm} / \mathrm{min}$, preload of 0.2 $\mathrm{cN} /$ tex, initial extension of $6 \%$, and retention period of 30 s. 15 measurements were taken. Seen in figure 4 , the variations in elastic recovery are not dramatically significant concerning the strand spacing. The elastic recovery increases with increasing spacing and then decreases when it reaches $17.5 \mathrm{~mm}$. With respect to the twist, it exhibits an ascending trend, which is the expected consequence of fortified cohesion of interfibers caused by higher twist, thus, restricts the mutual slippage [10]. As for the spindle speed, it exhibits a distinct upward trend. It increases dramatically up to $7000 \mathrm{rpm}$, beyond which it increases marginally.

\section{Yarn hairiness and unevenness}

The hairiness was measured by a YG172A hairiness tester on $100 \mathrm{~m}$ of yarns at $30 \mathrm{~m} / \mathrm{min}$. Figure 5 , a illustrates the effects of technological variables on the hairiness index $(\mathrm{HI})$. Note that the shape of curves is concave-down in all cases. The increase in strand spacing, twist and spindle speed result in a decrease 


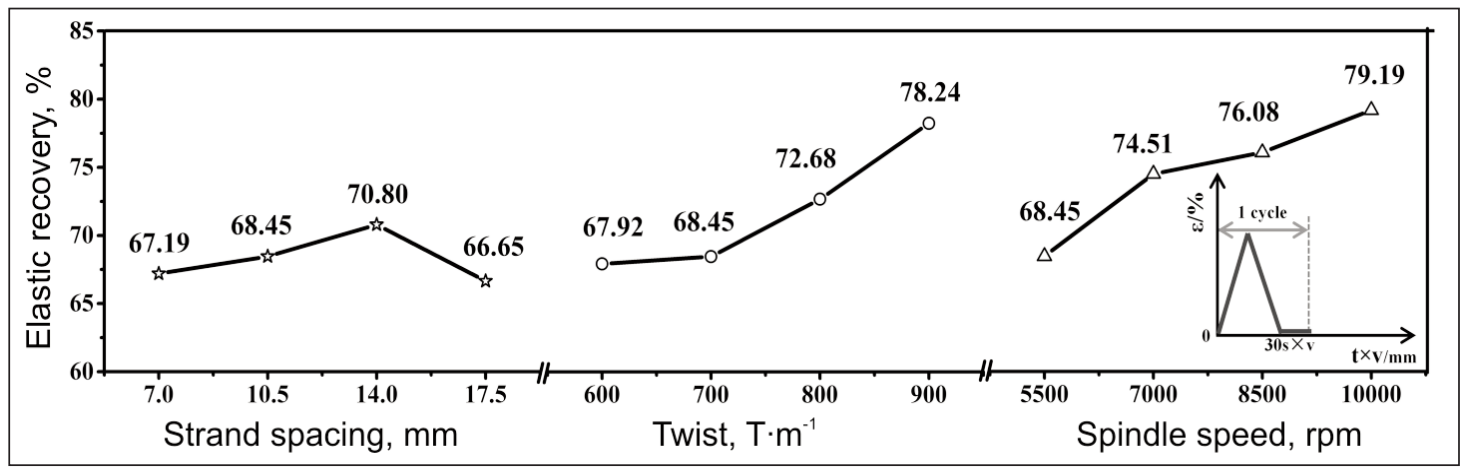

Fig. 4. Elastic recovery characteristics of t-ECCY specimens at varying process parameters

in yarn hairiness on the whole. Seen the histogram, S3 reduces by $60.7 \%$ when the spacing is increased from 7.0 to $10.5 \mathrm{~mm}$, but afterwards it increases gradually. Increased spacing results in greater strand length and strand angle leading to better trapping-in of surface fibers from strands at convergence point [7]. Also, the increased spacing causes loss in some short fibers [9]. However, the time-spending effect and totally uncontrolled process happen with further increasing spacing. The S3 values are lower with the increasing twist. As twist increases, more torque and cohesion are applied at twisting zone and thus the probability of fibers being embedded into the main body increases, and the draft fibers are easily controlled since the spinning geometry gets smaller (figure $2, b$ ). With increasing spindle speed, the hairiness decreases. The air turbulence and the spinning tension are responsible for the reduced hairiness.

A cut-weigh method was used to evaluate the unevenness. $10 \mathrm{~m}$ yarn with $1.2 \mathrm{cN} /$ tex preload was cut into 60 short-segments, the consecutive one was weighted. Thus, the mass of each length was plotted. The scatter of points will give a visual indication. Afterwards, the percentage mean deviation (PMD) and coefficient of variation (CV), were obtained. Results from figure $5, b$ signify that with increasing spacing up to $10.5 \mathrm{~mm}$, the unevenness decreases beyond which it increases marginally. Increasing twist was found to decrease the unevenness, mainly due to tighter packing density. However, there was no specific trend of variation with different speeds. By contrast, a higher speed was found to cause higher unevenness.
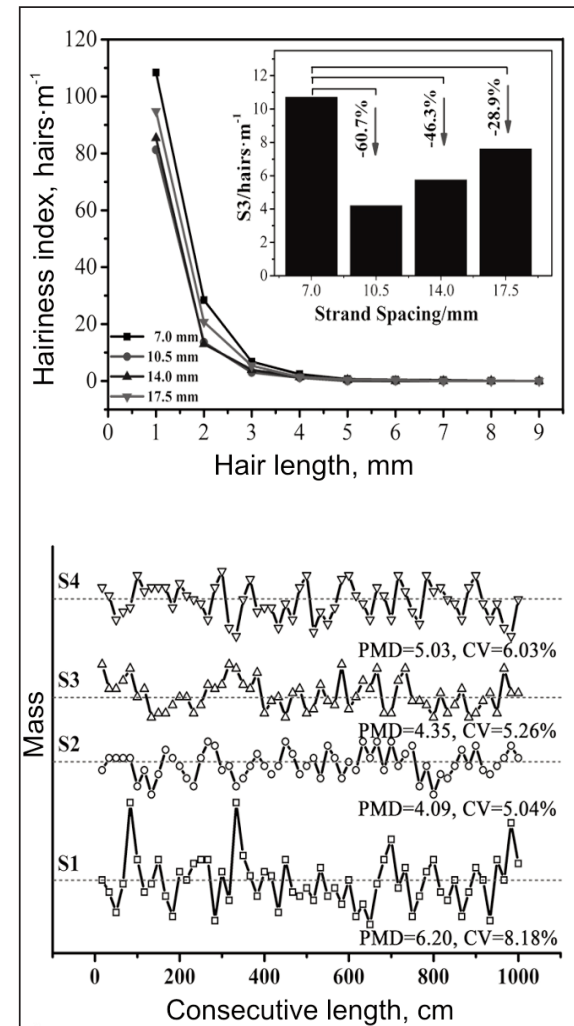

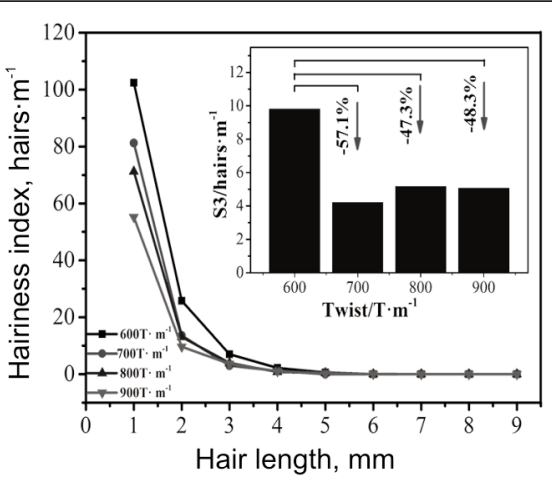

a

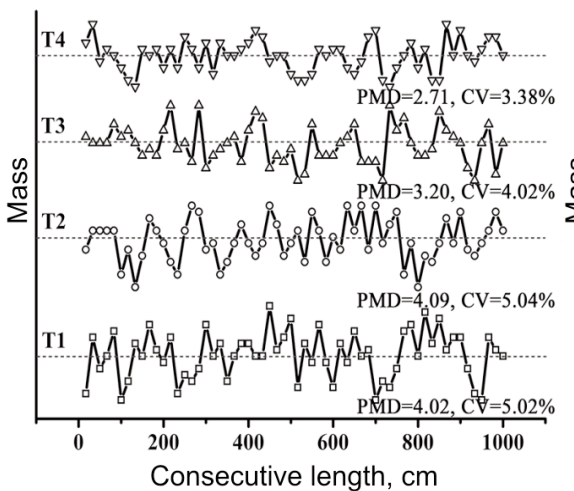

b
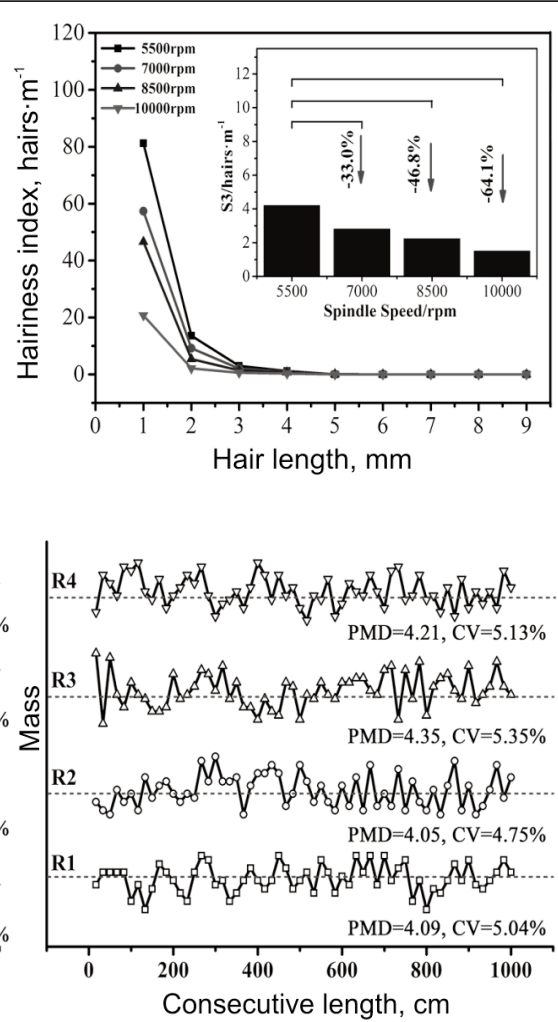

Fig. 5. a - effects of technological parameters, viz. strand spacing, twist, and spindle speed, on the yarn hairiness; $b$ - mass versus consecutive-length curves in terms of spinning parameters, and the calculated results 

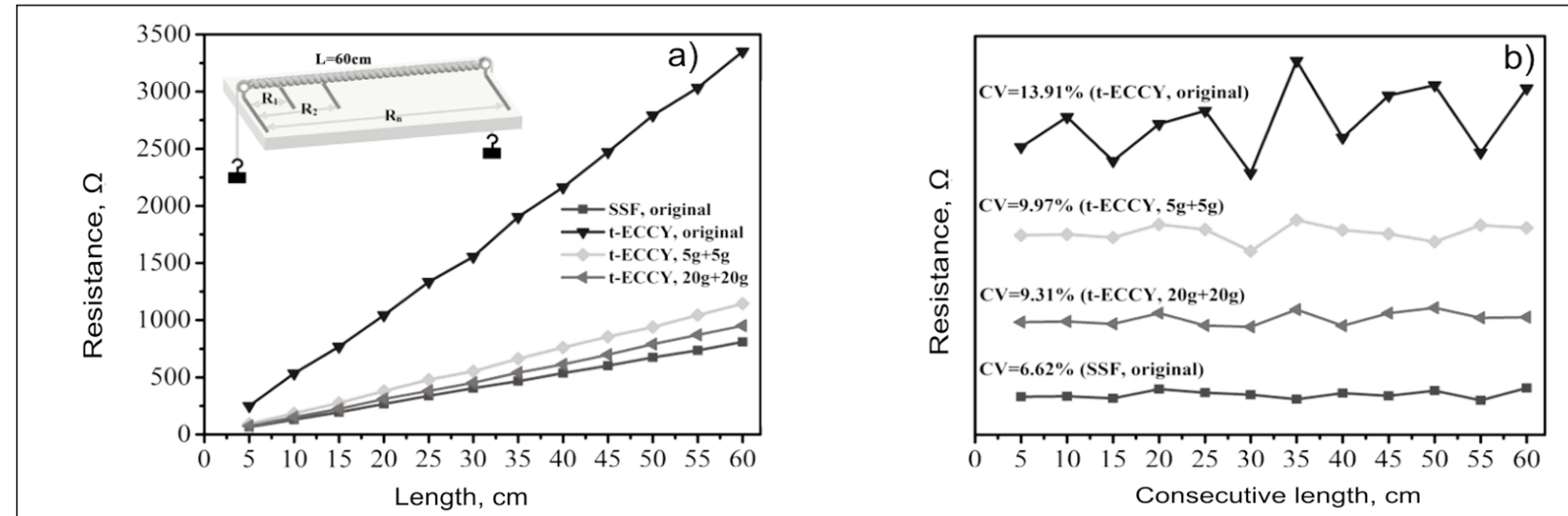

Fig. 6. $a-$ resistance and $b-\mathrm{CV}_{\mathrm{R}} \%$ plotted versus varying lengths and loadings of SSF and $\mathrm{t}-\mathrm{ECCY}$

\section{Electrical behaviour}

Considering the results above, it can be said that $\mathrm{t}$-ECCYs produced at $10.5 \mathrm{~mm}$ spacing, $700 \mathrm{~T} / \mathrm{m}$ twist, and $7000 \mathrm{rpm}$ spindle speed exhibited robust tensile properties, acceptable elasticity, lower hairiness and unevenness. Therefore, they were chosen for the subsequent electrical characterization. The resistance of $\mathrm{t}$-ECCYs was measured for varying lengths and loadings using two-electrode technique from the naked ends of SSF with an Applent AT510 resistance tester having 10 replications. Results in figure 6 , a showed that the resistance across varying intervals increased linearly with testing length of t-ECCYs with original state. The resistance of naked SSF was also measured. The SSF and t-ECCY have a linear relation to the length with a resistance of 13.5 and $56.5 \Omega / \mathrm{cm}$, respectively. When the loading was applied to the yarn ends, the actual length of SSF at a given testing length decreased. Consequently, the resistance maintained a linear dependence with descending slopes of $56.5,19.1$ and $15.9 \Omega / \mathrm{cm}$, respectively. Furthermore, the values of $\mathrm{CV}_{\mathrm{R}}$ of consecutive lengths of SSF and t-ECCY were illustrated in figure $6, b$. Linear change of $\mathrm{R}$ through the entire length regardless of original or tensional state suggests a uniform yarn structure and deformation. As a result, the t-ECCY itself can be used as a yarn-based sensor, which is more comfortable in wearing, easier to be fabricated by conventional textile process, better in style design [3].

\section{CONCLUSIONS}

A straightforward way to manufacture t-ECCYs based on a modified ring system was described, which employs EF as a core and SSF combining with rayon fibers as a helical winding around the core. Thereafter, a single factorial-analysis technique was applied to investigate the effects of spinning variables, viz., strand spacing, twist, and spindle speed, on some characteristics of resultant yarns. It was established that the preparatory process variables play a vital role in deciding the characteristics. Relationship between spinning geometry and performances was highlighted. The results revealed that t-ECCYs enjoyed robust tensile properties, acceptable elasticity, superior conductivity, lower hairiness and unevenness at strand spacing of $10.5 \mathrm{~mm}$, twist of $700 \mathrm{~T} / \mathrm{m}$, and spindle speed of $7000 \mathrm{rpm}$. As a result, such t-ECCYs could be a high-valuable proposition for special purposes in e-textiles. The yarn itself is available as a base sensor element, i.e., yarnbased sensor, and such yarns could be processed into fabric sensors easily. Such fabrics fulfilling the primary duties of textiles can be applied as lightweight miniature electronics in the future. Next, we aim to analysis the mutual relationships between processing parameters and spinning geometries theoretically and moreover, to construct woven and knitted fabric-sensors with the t-ECCYs, and to study the sensors' performance after single/cyclic stretchrecovery tests, washing, and in different climate conditions. Obviously, such work to address the issues would be very useful.

\section{ACKNOWLEDGEMENTS}

This work was supported by the Fundamental Research Funds for the Central Universities (CUSF-DH-D-2017018).

\section{BIBLIOGRAPHY}

[1] Rattfält, L., Lindén, M., Hult, P., Berglin, L., Ask, P. Electrical characteristics of conductive yarns and textile electrodes for medical applications, In: Medical \& Biological Engineering \& Computing, 2007, vol. 45, no. 12, pp. 1251-1257.

[2] Guo, L., Berglin, L., Mattila, H. Improvement of electro-mechanical properties of strain sensors made of elasticconductive hybrid yarns, In: Textile Research Journal, 2012, vol. 82, no. 19, pp. 1937-1947. 
[3] Huang, C.T., Tang, C.F., Lee, M.C., Chang, S.H. Parametric design of yarn-based piezoresistive sensors for smart textiles, In: Sensors and Actuators A: Physical, 2008, vol. 148, no. 1, pp. 10-15.

[4] Schwarz, A., Kazani, I., Cuny, L., Hertleer, C., Ghekiere, F., Clercq, G.D., Mey, G.D., Langenhove, L.V. Comparative study on the mechanical properties of elastic, electro-conductive hybrid yarns and their input materials, In: Textile Research Journal, 2011, vol. 81, no. 16, pp. 1713-1723.

[5] Ortlek, H.G., Kilic, G., Bilgin, S. Comparative study on the properties of yarns produced by modified ring spinning methods, In: Industria Textila, 2011, vol. 62, no. 3, pp. 129-133.

[6] Hua, T., Tao, X.M., Cheng, K.P.S., Xu, B.G. Effects of geometry of ring spinning triangle on yarn torque. Part I: analysis of fiber tension distribution, In: Textile Research Journal, 2007, vol. 77, no. 11, pp. 853-863.

[7] Cheng, K.P.S., Sun, M.N. Effect of strand spacing and twist multiplier on cotton sirospun yarn, In: Textile Research Journal, 1998, vol. 68, no. 7, pp. 520-527.

[8] Soltani, P., Johari, M.S. Effect of strand spacing and twist multiplier on structural and mechanical properties of siro-spun yarns, In: Fibers and Polymers, 2012, vol. 13, no. 1, pp. 110-117.

[9] Gowda, R.V.M., Sivakumar, M., Kannan, M.S.S. Influence of process variables on characteristics of modal siro-spun yarns using Box-Behnken response surface design, In: Indian Journal of Fibre and Textile Research, 2004, vol. 29, no. 4, pp. 412-418.

[10] Su, C.I., Yang, H.Y. Structure and elasticity of fine elastomeric yarns, In: Textile Research Journal, 2004, vol. 74, no. 12, pp. 1041-1044.

Authors:

\section{WANG YONG \\ YU WEIDONG \\ WANG FUMEI}

Donghua University, College of Textiles, Key Laboratory of Textile Science \& Technology, Ministry of Education, 2999 North Renmin Road, Songjiang District, 201620, Shanghai, P.R. China e-mail: yongwang0122@126.com,wdyu@dhu.edu.cn, wfumei@dhu.edu.cn

\section{Corresponding author:}

\section{YU WEIDONG}

e-mail: wdyu@dhu.edu.cn

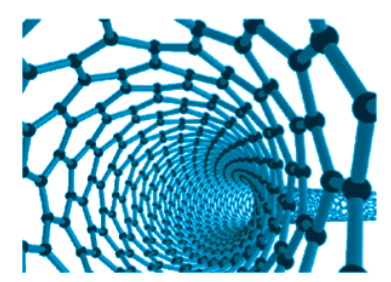

